\title{
Geochemical recycling
}

\section{Why continents look too young}

\author{
Paul Taylor
}

CAN the continental crust be recycled into the mantle whence it originally came? If transport of material from mantle to crust is essentially one-way traffic then a mean age can be determined for the continental crust using an appropriate radioactive decay scheme such as ${ }^{147} \mathrm{Sm}-{ }^{143} \mathrm{Nd}$, notwithstanding processes of crustal reworking which may effect internal redistribution of elements within the crust. (A mean age for the continental crust gives an important constraint on models of the development of the continental crust.) But if recycling does occur then the crust is a 'leaky' system, and more complex interactions with the mantle must be considered in geochemical models. In fact, it seems that the evidence for or against recycling is highly dependent on the chemical elements under consideration. On page 733 of this issue', Goldstein shows that removal of radiogenic strontium from the crust causes serious underestimation of the mean age of the continents by the ${ }^{x 7} \mathrm{Rb}-{ }^{x 7} \mathrm{Sr}$ decay scheme.

It is accepted that the buoyancy of continental (sialic) crust inhibits the bulk return of such material to the mantle. However, other mechanisms for returning some crustal constituents to the mantle have been proposed and debated. Sediments derived from the continents and deposited on the ocean floor might be carried down on the descending plate at subduction zones. Elements leached from continental rocks by weathering are carried by the rivers to the oceans in solution. Some of this material is incorporated into the oceanic crust by hydrothermal interaction at mid-ocean ridges and by low temperature alteration processes. For those elements carried in sediments on the oceanic 'conveyor belt' ( $\mathrm{Pb}, \mathrm{Ce}, \mathrm{Lu}, \mathrm{Hf}$, $\mathrm{Sm}$ and $\mathrm{Nd}$ ), the evidence is against deep recycling into the convecting mantle ${ }^{2.3}$. (Incorporation of subducted sediments into magmas for rapid return to the crust through island-arc volcanism probably serves as a filter preventing deep recycling.)

The Sm-Nd decay scheme provides a reliable basis for determining crustal residence ages because once these elements have been incorporated into the continental crust they are not lost, either by sediment subduction (see above) or by weathering and leaching ( $\mathrm{Sm}$ and $\mathrm{Nd}$ are virtually insoluble in water). The $\mathrm{Sm}-\mathrm{Nd}$ isotope 'clock' is based on the radioactive decay of ${ }^{147} \mathrm{Sm}$ to ${ }^{1+3} \mathrm{Nd}$ by $\alpha$-emission. At the time of formation, continental crust acquires a markedly lower $\mathrm{Sm} / \mathrm{Nd}$ ratio than that typical of its mantle source, with the consequence that the rate of change of ${ }^{1+3} \mathrm{Nd} /{ }^{1+4} \mathrm{Nd}$ ratios is significantly less in the crust than in the mantle. $\left({ }^{1+} \mathrm{Nd}\right.$ is a stable isotope of $\mathrm{Nd}$, neither radioactive nor radiogenic. It is used as a reference isotope against which variations in the abundances of the parent ${ }^{1+7} \mathrm{Sm}$ and daughter ${ }^{143} \mathrm{Nd}$ isotopes can be measured.) The separation of the crust from the mantle effectively starts the isotope clock, and the crustal residence age is assessed from the contrast in the present $\mathrm{Sm}-\mathrm{Nd}$ isotope compositions of the crustal sample and mantle.

Crust-mantle differentiation is apparently the main process during which fractionation of Sm-Nd ratios occurs. Subsequent crustal reworking events, whether sedimentary, igneous or metamorphic, seem to have little effect on these ratios, such that the memory of the initial crust formation age can be retained.

\section{0 years ago \\ THE EARLIEST}

RACIAL PORTRAITS THE earliest representations of races have been strangely neglected hitherto. At the desire of the British Association I took up this work, and made a series of casts of 280 heads from the sculptures, besides noting the colours of all paintings of races that I could find.

The photograph shows the Thahennu of Northern Africa, the Kabyles of modern times.

W. M. Flinders Pfitrie:

From Nature 39, 128; 6 December 1888.
In his paper in this issue ${ }^{1}$, Goldstein contrasts the behaviour of the Sm-Nd decay scheme with the related $\mathrm{Rb}-\mathrm{Sr}$ decay scheme used in earlier dating studies. The $\mathrm{Rb}-\mathrm{Sr}$ decay scheme gives apparent crustal residence ages which are generally much younger than Sm-Nd model ages, especially for clastic sedimentary rocks. Goldstein shows that $\mathrm{Rb}$ and $\mathrm{Sr}$ can be strongly fractionated by intra-crustal processes, not least in the sedimentary cycle of weathering-erosion-transportdeposition-diagenesis. Whereas Sm and $\mathrm{Nd}$ are virtually insoluble in water, weathering processes can remove $\mathrm{Sr}$ in solution and concentrate $\mathrm{Rb}$ in clays. This causes a pronounced fractionation of $\mathrm{Rb}$ and $\mathrm{Sr}$, and removes generally radiogenic $\mathrm{Sr}$ from the continental crust to the ocean basins. Some of this $\mathrm{Sr}$ can then be loaded onto the subduction conveyor belt by hydrothermal interaction of sea water with oceanic basalts ${ }^{4}$, by low temperature alteration reactions on the sea floor ${ }^{5}$, and by deposition of pelagic carbonates.

The return of this $\mathrm{Sr}$ to the mantle is not directly proved by Goldstein's study, but he argues persuasively from several strands of circumstantial evidence that such return feed has taken place. First, no volumetrically significant reservoir of unsupported radiogenic $\mathrm{Sr}$ has been recognized within the continental crust as a complement to the material which has lost radiogenic Sr. Secondly, the systematic loss of radiogenic $\mathrm{Sr}$ from the continental crust can account for the near-stagnation of ${ }^{87} \mathrm{Sr} /{ }^{86} \mathrm{Sr}$ in sea water through much of the Earth's later history, and for the lowering of initial ${ }^{87} \mathrm{Sr} /{ }^{86} \mathrm{Sr}$ ratios of many rock-units formed by crustal reworking. As a result of this latter effect, the $\mathrm{Rb}-\mathrm{Sr}$ method results in underestimation of continental crustal residence ages, with serious consequences for some continental growth models ${ }^{6}$.

Finally, Goldstein also demonstrates that the return of continental $\mathrm{Sr}$ to the mantle could account for a very significant proportion of the total change in mantle $\mathrm{Sr}$ isotopic composition over the Earth's history, with serious implications for our understanding of the geochemical evolution of the mantle. This new work clearly impinges on studies of evolution of the continental crust, sea water and the upper mantle, plausibly resolving some previously enigmatic observations and placing several items of conventional wisdom under renewed scrutiny.

\footnotetext{
1. Goldstein. S.L. Nature 336, 733-738 (1988),

Newsom. H.E., White. W.M. Jochum, K.P. \& Hofmann, A.W. Earth planet. Sci. Lett. 80, 299-313(1986)

Patchett. P.J.. White, W.M.. Feldmann, H. . Kielinczuk. S \& Hofmann. A.W. Earth planer. Sci. Lett. 69.365-378 (1984) Albarède. F. et al. Earth planet. Sci. Lett. 55, 229-236 (1981). Staudigel. H. \& Hart. S.R. Geochim. cosmochim. Acta 47 $337-350$ (1983).

6. Hurley, P.M. \& Rand. J.R. Science 164. 1229-1242 (1969)
}

Paul Taylor is in the Department of Earth Sciences, University of Oxford, Parks Road, Oxford $O X 13 P R, U K$. 